\title{
KEMAMPUAN LARUTAN KUBIS DALAM MENGAWETKAN IKAN Haderiah $^{1}$ dan Ade Isfi Hayatul Ufa ${ }^{2}$ \\ 1,2Jurusan Kesehatan Lingkungan Poltekkes Kemenkes Makassar adeisfihayatulufa@gmail.com
}

\begin{abstract}
The waste of cabbage that are generally no longer used can turn out to be a way out for the community to be preserved fish, rather than using hazardous materials to preserve fish, which can harm human health. The utilization of this cabbage waste in the process of fermentation can produce lactic acid bacteria that can inhibit the process of the decomposition in fish because it kills bacteria. The purpose of this research is to know the ability of cabbage solvent in preserving fish. The type of research used is laboratory experiment that is to know the ability of cabbage solvent in preserving fish where the results of research were processed manually and presented in table form then narrated. Based on the results of research and discussion about the ability of cabbage solvent in preserving fish, it was found that cabbage solvent with 3 days fermentation time was able to preserve fish that had been cleaned for 12 hours, and able to preserve fish that was not cleaned for 9 hours while cabbage solvent with fermentation length 6 days was able to preserve fish that had been cleaned for 12 hours and able to preserve fish that was not cleaned for 10 hours and cabbage solvent with a long fermentation of 9 days can preserve fish that had been cleaned for 8 hours and able to preserve fish that was not cleaned for 6 hours. It is necessary to raise the awareness of the communities to use natural preservatives to preserve fish instead of using artificial preservatives that can endanger health

Keywords: Fermentation of Cabbage Waste, Fish
\end{abstract}

\section{ABSTRAK}

Limbah kubis yang umumnya sudah tidak dapat digunakan lagi ternyata bisa menjadi jalan keluar bagi masyarakat untuk dijadikan pengawet ikan, dibanding menggunakan bahan yang berbahaya untuk mengawetkan ikan, yang dapat mengganggu kesehatan manusia. Pemanfaatan limbah kubis ini dalam proses fermentasi dapat menghasilkan bakteri asam laktat yang dapat menghambat proses pembusukan pada ikan karena bersifat membunuh bakteri pembusuk. Tujuan penelitian ini adalah untuk mengetahui kemampuan larutan kubis dalam mengawetkan ikan. Jenis penelitian yang digunakan adalah eksperimen laboratorium yaitu untuk mengetahui kemampuan larutan kubis dalam mengawetkan ikan hasil penelitian diolah secara manual dan disajikan dalam bentuk tabel kemudian dinarasikan. Berdasarkan hasil penelitian mengenai kemampuan larutan kubis dalam mengawetkan ikan dapat disimpulkan bahwa larutan kubis dengan lama fermentasi 3 hari mampu mengawetkan ikan yang sudah dibersihkan selama 12 jam, dan mampu mengawetkan ikan yang tidak di bersihkan selama 9 jam sedangkan larutan kubis dengan lama fermentasi 6 hari mampu mengawetkan ikan yang sudah dibersihkan selama 12 jam dan mampu mengawetkan ikan yang tidak dibersihkan selama 10 jam dan larutan kubis dengan lama fermentasi 9 hari mampu mengawetkan ikan yang sudah dibersihkan selama 8 jam dan mampu mengawetkan ikan yang tidak dibersihkan selama 6 jam.

Keyword: Fermentasi Limbah Kubis, Ikan

\section{PENDAHULUAN}

Ikan merupakan sumber protein utama, penduduk di wilayah kepulauan namun dengan kandungan protein dan air yang cukup tinggi menyebabkan ikan mudah mengalami proses pembusukan, serta bakteri dan perubahan kimiawi pada ikan mati menyebabkan pembusukan, penanganan ikan perlu dilakukan agar tetap segar dan bisa dinikmati masyarakat dengan tidak menyebabkan dampak negatif terhadap kesehatan manusia. Salah satu penanganan ikan yang dapat dilakukan adalah dengan teknik pengawetan agar ikan tetap segar sampai ke konsumen.

Penggunaan formalin sebagai bahan pengawet pada makanan di Indonesia banyak sekali dilakukan secara illegal terutama untuk pengawetan ikan segar. Hal ini merupakan bentuk penyalahgunaan fungsi dari formalin. Formalin tidak diperkenankan ada dalam makanan maupun minuman, karena dalam jangka panjang dapat memicu perkembangan sel-sel kanker. Produsen secara diam-diam melakukan hal ini karena belum menemukan jalan keluar untuk dapat mempertahankan kualitas ikan dalam jangka waktu yang lama dengan menggunakan pengawet alami yang ada saat ini. Masalah ini dapat diatasi dengan mencari alternantif bahan pengawet makanan yang mudah dan efisien.

Limbah kubis yang umumnya sudah tidak dapat digunakan lagi ternyata bisa menjadi jalan keluar bagi masalah ini. Pemanfaatan limbah kubis ini dalam proses fermentasi dapat menghasilkan bakteri asam laktat yang dapat menghambat proses pembusukan pada ikan karena bersifat membunuh bakteri pembusuk. (Siagian,L. T. I., 2012)

\section{BAHAN DAN METODE}

\section{Lokasi Penelitian}

Lokasi Pengambilan sampel ikan yaitu di Pelabuhan Paotere dan pengambilan sampel kubis yaitu di pasar pa'baeng-baeng dalam penelitian ini dilakukan pengamatan dilaksanakan di jl.Wijaya Kusuma 1 No 21.

\section{Desain dan Variabel}


a) Desain

Teknik pengawetan ikan yang dilakukan dalam penelitian ini yaitu limbah kubis ini ditambahkan garam 2,5\% yang akan dimanfaatkan sebagai fermentasi untuk mengawetkan ikan yang akan di teliti

b) Variabel Penelitian

Variabel bebas dalam penelitian ini yaitu lama fermentasi 3 hari, 6 hari, dan 9 hari sedangkan variabel terikatnya yaitu waktu simpan.

\section{Metode Pengumpulan Data}

a) Data Primer

\section{Data}

berdasarkan

kemampuan

$\begin{array}{cr}\text { primer } & \text { diperoleh } \\ \text { pengamatan } & \text { tentang } \\ \text { larutan kubis } & \text { dalam } \\ \text { ikan sebagai } & \text { sampel }\end{array}$ penelitian.

b) Data sekunder

Data sekunder yang diperoleh dari artikel-artikel yang mendukung teori, penelitian sebelumnya serta literatur lain yang dianggap berhubungan dengan penelitian ini.

c) Teknik Analisa Data

Data yang diperoleh berdasarkan hasil pengamatan yang didapat pada saat melaksanakan eksperimen dan dianalisa secara deskriptif.

d) Penyajian Data

Penyajian data yang diperoleh berdasarkan hasil pengamatan yang didapat pada saat melaksanakan eksperimen dan disajikan dalam bentuk tabel dan dinarasikan.

\section{HASIL PENELITIAN}

1) Kemampuan Larutan Kubis dengan Lama Fermentasi 3 Hari
Tabel 1

Kemampuan Larutan Kubis dengan Lama Fermentasi 3 Hari

\begin{tabular}{|c|c|c|c|}
\hline \multicolumn{4}{|c|}{ Daya Awet Ikan (jam) } \\
\hline No & Perlakuan & Dibersihkan & $\begin{array}{c}\text { Tidak } \\
\text { Dibersihkan }\end{array}$ \\
\hline \multirow{3}{*}{1} & Tanpa Perlakı & & \\
\hline & 1 & 4 & 3 \\
\hline & II & 4 & 3 \\
\hline & Rata-rata & 4 & 3 \\
\hline \multirow{3}{*}{2} & Pelumuran Ga & & \\
\hline & 1 & 7 & 6 \\
\hline & II & 7 & 6 \\
\hline & Rata-rata & 7 & 6 \\
\hline \multirow{4}{*}{3} & Fermentasi $3 \mathrm{H}$ & & \\
\hline & 1 & 10 & 9 \\
\hline & II & 10 & 9 \\
\hline & Rata-rata & 10 & 9 \\
\hline
\end{tabular}

\section{2) Kemampuan Larutan Kubis dengan Lama Fermentasi 6 Hari}

Tabel 2

Kemampuan Larutan Kubis dengan lama fermentasi 6 hari

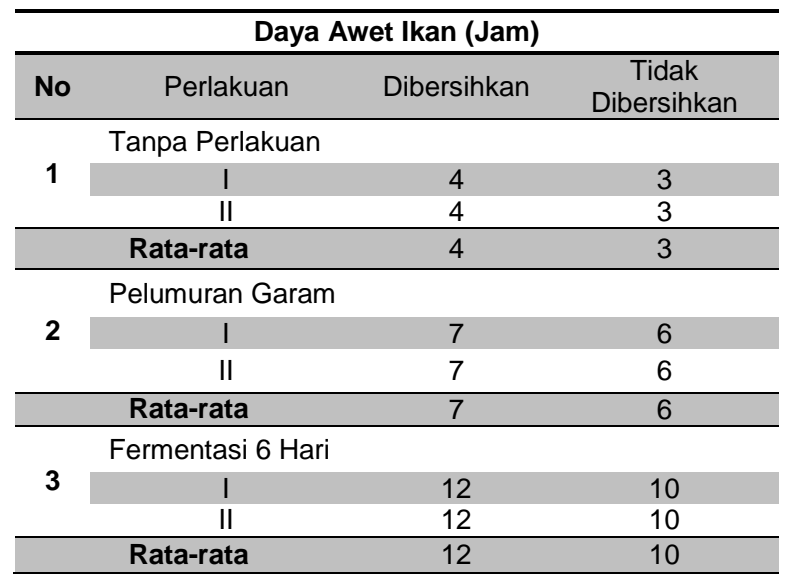


Jurnal Sulolipu : Media Komunikasi Sivitas Akademika dan Masyarakat

Vol. 17 No.II 2017

e-issn : 2622-6960, p-issn : 0854-624X

3) Kemampuan Larutan Kubis dengan Lama Fermentasi 9 Hari

Tabel 3

Kemampuan Larutan Kubis dengan lama fermentasi 9 hari

\begin{tabular}{|c|c|c|c|}
\hline \multicolumn{4}{|c|}{ Daya Awet Ikan(Jam) } \\
\hline No & Perlakuan & Dibersihkan & $\begin{array}{c}\text { Tidak } \\
\text { Dibersihkan }\end{array}$ \\
\hline \multirow{3}{*}{1} & $\begin{array}{l}\text { Tanpa } \\
\text { Perlakuan }\end{array}$ & & \\
\hline & I & 4 & 3 \\
\hline & II & 4 & 3 \\
\hline & Rata-rata & 4 & 3 \\
\hline \multirow{4}{*}{2} & $\begin{array}{c}\text { Pelumuran } \\
\text { Garam }\end{array}$ & & \\
\hline & I & 7 & 6 \\
\hline & II & 7 & 6 \\
\hline & Rata-rata & 7 & 6 \\
\hline \multirow{4}{*}{3} & $\begin{array}{c}\text { Fermentasi } 9 \\
\text { Hari }\end{array}$ & & \\
\hline & I & 8 & 8 \\
\hline & II & 8 & 8 \\
\hline & Rata-rata & 8 & 8 \\
\hline
\end{tabular}

\section{PEMBAHASAN}

1) Kemampuan Larutan Kubis dalam mengawetkan ikan dengan lama Fermentasi 3 Hari

a) Tanpa Perlakuan

Berdasarkan hasil penelitian yang telah dilakukan untuk ikan yang dibersihkan tanpa perlakuan didapatkan masa bertahan selama 4 jam Pada saat pengamatan ikan yang dibersihkan dari hasil pengamatan fisik yang telah dilakukan maka hasil yang didapatkan mata pada ikan ini bola mata sangat cekung, kornea sangat keruh, pupil abu-abu, tidak mengkilap ikan yang telah diamati sudah menimbulkan bau asam kuat, lendir sudah menggumpal, daging sudah kusam, dan tekstur sangat lunak dan bekas jari tidak hilang.

Sedangkan ikan tanpa perlakuan yang tidak dibersihkan didapatkan masa bertahan selama 3 jam dari hasil pengamatan fisik yang telah dilakukan maka hasil yang didapatkan mata pada ikan ini mulai mengalami kornea keruh, pupil keabuabuan, dan tidak mengkilap ikan yang telah diamati sudah menimbulkan bau asam kuat, lendir sudah menggumpal, daging sudah kusam, dan tekstur sangat lunak dan bekas jari tidak hilang.

b) Pelumuran Garam

Berdasarkan hasil penelitian yang telah dilakukan untuk ikan yang dibersihkan dengan pelumuran garam didapatkan masa bertahan selama 7 jam, Pada saat pengamatan ikan yang dibersihkan dari hasil pengamatan fisik yang telah dilakukan maka hasil yang didapatkan mata pada ikan ini bola mata sangat cekung, kornea sangat keruh, pupil abu-abu, tidak mengkilap ikan yang telah diamati

sudah menimbulkan bau asam kuat, lendir sudah menggumpal, daging sudah kusam, dan tekstur sangat lunak dan bekas jari tidak hilang.

Sedangkan ikan yang dilumuri garam yang tidak dibersihkan didapatkan masa bertahan selama 6 jam dari hasil pengamatan fisik yang telah dilakukan maka hasil yang didapatkan mata pada ikan ini mulai mengalami kornea keruh, pupil keabuabuan, dan tidak mengkilap ikan yang telah diamati sudah menimbulkan bau asam kuat, lendir sudah menggumpal, daging sudah kusam, dan tekstur sangat lunak dan bekas jari tidak hilang.

c) Fermentasi 3 Hari

Berdasarkan hasil limbah kubis yang diiris dimana limbah kubis ini ditambahkan garam $2,5 \%$ yang akan dimanfaatkan sebagai fermentasi untuk mengawetkan ikan yang akan di teliti dimana didapatkan hasil fermentasi kubis untuk ikan yang dibersihkan di dapatkan ikan yang memiliki daya awet selama 10 jam. Berdasarkan hasil pengamatan organoleptik pada jam ke 1-6 diperoleh nilai 9 dengan spesifikasi Mata cembung, kornea dan pupil jerni, mengkilap spesifik jenis ikan. Sayatan daging sangat cemerlang, spesifik jenis, jaringan daging sangat kuat. Bau sangat segar, spesifik jenis kuat dan tekstur padat, kompak dan sangat elastis.

2) Kemampuan Larutan Kubis Dalam Mengawetkan Ikan Dengan Lama Fermentasi 6 Hari

a) Tanpa Perlakuan

Berdasarkan hasil penelitian yang telah dilakukan untuk ikan yang dibersihkan tanpa perlakuan didapatkan masa bertahan selama 4 jam, Pada saat pengamatan ikan yang dibersihkan dari hasil pengamatan fisik 
yang telah dilakukan maka hasil yang didapatkan mata pada ikan ini bola mata sangat cekung, kornea sangat keruh, pupil abu-abu, tidak mengkilap ikan yang telah diamati sudah menimbulkan bau asam kuat, lendir sudah menggumpal, daging sudah kusam, dan tekstur sangat lunak dan bekas jari tidak hilang.

Sedangkan ikan tanpa perlakuan yang tidak dibersihkan didapatkan masa bertahan selama 3 jam dari hasil pengamatan fisik yang telah dilakukan maka hasil yang didapatkan mata pada ikan ini mulai mengalami kornea keruh, pupil keabuabuan, dan tidak mengkilap ikan yang telah diamati sudah menimbulkan bau asam kuat, lendir sudah menggumpal, daging sudah kusam, dan tekstur sangat lunak dan bekas jari tidak hilang.

b) Pelumuran Garam

Berdasarkan hasil penelitian yang telah dilakukan untuk ikan yang dibersihkan dengan pelumuran garam didapatkan masa bertahan selama 7 jam, Pada saat pengamatan ikan yang dibersihkan dari hasil pengamatan fisik yang telah dilakukan maka hasil yang didapatkan mata pada ikan ini bola mata sangat cekung, kornea sangat keruh, pupil abu-abu, tidak mengkilap ikan yang telah diamati sudah menimbulkan bau asam kuat, lendir sudah

menggumpal, daging sudah kusam, dan tekstur sangat lunak dan bekas jari tidak hilang.

Sedangkan ikan yang dilumuri garam yang tidak dibersihkan didapatkan masa bertahan selama 6 jam dari hasil pengamatan fisik yang telah dilakukan maka hasil yang didapatkan mata pada ikan ini mulai mengalami kornea keruh, pupil keabuabuan, dan tidak mengkilap ikan yang telah diamati sudah menimbulkan bau asam kuat, lendir sudah menggumpal, daging sudah kusam, dan tekstur sangat lunak dan bekas jari tidak hilang.

c) Fermentasi 6 Hari

Berdasarkan hasil limbah kubis yang diiris lalu ditimbang seberat $750 \mathrm{gr}$ kemudian ditambahkan garam $2,5 \%$, proses pembuatan fermentasi memiliki selingan waktu selama 3 hari untuk mendapatkan fermentasi 6 hari yang akan dimanfaatkan sebagai fermentasi untuk mengawetkan ikan yang akan diteliti dimana didapatkan hasil fermentasi kubis untuk ikan yang dibersihkan didapatkan hasil yang memiliki daya awet selama 12 jam Berdasarkan hasil pengamatan organoleptik pada jam ke 1-6 diperoleh nilai 9 dengan spesifikasi Mata cembung, kornea dan pupil jerni, mengkilap spesifik jenis ikan. Sayatan daging sangat cemerlang, spesifik jenis, jaringan daging sangat kuat. Bau sangat segar, spesifik jenis kuat dan tekstur padat, kompak dan sangat elastis.

3) Kemampuan Larutan Kubis dalam mengawetkan ikan dengan lama Fermentasi 9 Hari

a) Tanpa Perlakuan

Berdasarkan hasil penelitian yang telah dilakukan untuk ikan yang dibersihkan tanpa perlakuan didapatkan masa bertahan selama 4 jam, Pada saat pengamatan ikan yang dibersihkan dari hasil pengamatan fisik yang telah dilakukan maka hasil yang didapatkan mata pada ikan ini bola mata sangat cekung, kornea sangat keruh, pupil abu-abu, tidak mengkilap ikan yang telah diamati sudah menimbulkan bau asam kuat, lendir sudah menggumpal, daging sudah kusam, dan tekstur sangat lunak dan bekas jari tidak hilang.

Sedangkan ikan tanpa perlakuan yang tidak dibersihkan dari hasil pengamatan fisik yang telah dilakukan maka hasil yang didapatkan mata pada ikan ini mulai mengalami kornea keruh, pupil keabuabuan, dan tidak mengkilap ikan yang telah diamati sudah menimbulkan bau asam kuat, lendir sudah menggumpal, daging sudah kusam, dan tekstur sangat lunak dan bekas jari tidak hilang.

b) Pelumuran Garam

Berdasarkan hasil penelitian yang telah dilakukan untuk ikan yang dibersihkan dengan pelumuran garam didapatkan masa bertahan selama 7 jam, Pada saat pengamatan ikan yang dibersihkan dari hasil pengamatan fisik yang telah dilakukan maka hasil yang didapatkan mata pada ikan ini bola mata sangat cekung, kornea sangat keruh, pupil abu-abu, tidak mengkilap ikan yang telah diamati sudah menimbulkan bau asam kuat, lendir sudah menggumpal, daging sudah kusam, dan tekstur sangat lunak dan bekas jari tidak hilang.

Sedangkan ikan yang dilumuri garam yang tidak dibersihkan didapatkan masa 
Jurnal Sulolipu : Media Komunikasi Sivitas Akademika dan Masyarakat

Vol. 17 No.II 2017

e-issn : 2622-6960, p-issn : 0854-624X

bertahan selama 6 jam dari hasil pengamatan fisik yang telah dilakukan maka hasil yang didapatkan mata pada ikan ini mulai mengalami kornea keruh, pupil keabuabuan, dan tidak mengkilap ikan yang telah diamati sudah menimbulkan bau asam kuat, lendir sudah menggumpal, daging sudah kusam, dan tekstur sangat lunak dan bekas jari tidak hilang.

c) Fermentasi 9 Hari

Berdasarkan hasil fermentasi kubis yang dilakukan selama 9 hari pada saat ikan direndam menggunakan larutan kubis hanya mampu bertahan selama 8 jam berdasarkan hasil pengamatan organoleptik pada jam ke 1-6 diperoleh nilai 9 dengan spesifikasi Mata cembung, kornea dan pupil jerni, mengkilap spesifik jenis ikan. Sayatan daging sangat cemerlang, spesifik jenis, jaringan daging sangat kuat. Bau sangat segar, spesifik jenis kuat dan tekstur padat, kompak dan sangat elastis.

\section{PENUTUP}

\section{Kesimpulan}

Berdasarkan hasil penelitian dan pembahasan mengenai Kemampuan Larutan Kubis dalam mengawetkan ikan dengan lama perendaman maka dapat disimpulkan bahwa larutan kubis dapat mengawetkan ikan 6-12 jam dengan uraian sebagai berikut:

a) Kemampuan Larutan kubis dalam mengawetkan ikan dengan lama fermentasi 3 hari mampu mengawetkan ikan yang sudah dibersihkan selama 10 jam, dan mampu mengawetkan ikan yang tidak di bersihkan selama 9 jam.

b) Kemampuan larutan kubis dalam mengawetkan ikan dengan lama fermentasi 6 hari mampu mengawetkan ikan yang sudah dibersihkan selama 12 jam dan mampu mengawetkan ikan yang tidak dibersihkan selama 10 jam.

c) Kemampuan larutan kubis dalam mengawetkan ikan dengan lama fermentasi 9 hari mampu mengawetkan ikan yang sudah dibersihkan selama 8 jam dan mampu mengawetkan ikan yang tidak dibersihkan selama 8 jam.

\section{Saran}

Diharapkan kepada masyarakat untuk memanfaatkan larutan fermentasi kubis sebagai pengawet alami pada ikan, dan sebelum memasak atau menggoreng ikan sebaiknya ikan dicuci hingga bersih terlebih dahulu agar rasa kubis pada ikan berkurang.

\section{DAFTAR PUSTAKA}

Adams, Martin`R., Maurice O. Moss. 2008. Food Microbiology, Third Edition. Guildford, UK: RSC Publishing

Cahyo Saparinto dan Diana Hidayati. 2010. Bahan Tambahan Pangan. Yogyakarta: Kanisius, cetakan kelima

Cecep Dani Sucipto. 2016. Keamanan Pangan Untuk Kesehatan Manusia. Yogyakarta:Gosyen Publishing

Eddy Afrianto dan Evy Liviawaty. 2011. Pengawetan Dan Pengolahan Ikan. Yogyakarta: Kanisius, cetakan ketujuh belas

Leni Herliani Afrianti. 2013. Teknologi Pengawetan Pangan. Bandung:Alfabeta, cetakan kedua

Said Siregar, dkk, 2015. Pemanfaatan Limbah Kubis (Brassica oleracea) Sebagai Bahan Pengawet Ikan Nila(Oreochromis sp). $\quad$ http://download.portalgaruda.org/ article.php?article=393404\&val=6157\&title=UTILIZATION\%20OF\%20CABBAGE\%20WASTE\%2 0(Brassica\%20oleracea)\%20AS\%20A\%20PRESERVATIVE\%20OF\%20PARROT\%20FISH\%20( Oreochromis\%20sp). diakses tanggal 10 Maret 2017. 
Jurnal Sulolipu : Media Komunikasi Sivitas Akademika dan Masyarakat Vol. 17 No.II 2017

e-issn : 2622-6960, p-issn : 0854-624X

Siagian,L. T. I., 2012. Larutan Hasil Fermentasi Limbah Kubis Sebagai Pengawet Alami Ikan Segar, Program Studi Teknik Elektro Fakultas Teknik Universitas Hkbp Nommensen Medan

Syamsidar. 2013. Kemampuan Larutan Kubis(Brassica oleraccea L) Dalam mengawetkan Ikan Dengan Lama Perendaman. Makassar: Program studi DIII Jurusan Kesehatan Lingkungan. Makassar Politeknik Kesehatan Makassar 